Michat Mrugalski*

\title{
From representation to enactment: temporal perspectives on literary objects in East and Central European structuralism and Ingarden's phenomenology
}

https://doi.org/10.1515/fns-2018-0036

Abstract: Considering that enacitivsm emerged in rebellion against the representativism of first-generation cognitive science, an enactivist approach to narrative, which after all does relate events, situations, people, necessitates a directly realistic (i.e. anti-representationalist) concept of perspective on literary objects. Ingarden's description of the spatio-temporal properties of the cognizing of the literary work, in the process of which the reader transgresses the realm of signs (representation) toward embodied and culturally embedded cognition of objects and events in a presented world, may serve as a prototype for an enactive approach narrative, provided the theory in question is situated in its original context, for example that of Ingarden's ongoing discussion with structuralism regarded at this juncture as a representationist stance. In the first step, I am referring to the philosophical tradition of direct realism, which was apparently invigorated by the theories of embodied and enactive cognition, to propose a way of conceiving first-person perspective on literary objects and events, first-person and temporal perspective on objects being the royal road to all sorts of enaction. In the second step, I am tackling the issue of point of view in East and Central European structuralism by recalling its most general context of the dialectical relationship between synchrony and diachrony. The interpretation of linguistic signs by the receiver is a space in which structuralism and Ingarden's phenomenology concur as they share a similar model of receptive temporality, rooted in Husserl's description of the inner consciousness of time and aiming to reduce the ambiguity of linguistic units and increase the predictability of meaning. In Ingarden, however, there is a threshold between the linguistic and the extralinguistic elements of the literary work, which are conceived in a directly realistic manner. I specifically recall the notion of "objectification," which was suppressed by that of "concretization," as a borderland between indirect (semiotic) and indirect (objec-

*Corresponding author: Michat Mrugalski, Humboldt University of Berlin, Institute of Slavic and Hungarian Studies, Unter den Linden 6, 10099 Berlin, E-Mail: Michal.mrugalski@hu-berlin.de 
tual and enactive) representation. In the conclusion, I point to the major differences between present-day cognitivist aesthetics and Ingarden's approach, which was immersed in the culture of his time, and ask whether these differences impede us to achieve as interesting results as Ingarden's.

Keywords: enaction, point of view, direct realism, time-consciousness, aesthetical experience

\section{Introduction}

If post-classical approaches in narratology are defined as based on, or supplementing “classical," structuralist methods (cf. Herman 1997, Herman 1999; Prince 2008; Alber and Fludernik 2010 eds.; Fludernik and Olson 2011; Sommer 2012; cf. Pier 2011), Roman Ingarden's detailed description of the spatio-temporal properties of the reading and cognizing of the literary work, in which elements akin to structural-semiological approaches coincide with environmental and experiential moments, may serve as a prototype for a post-classical attitude. In particular, as Ingarden goes beyond semio-structural narratology in the directions of cultural situatedness and embodied cognition, his account of reading may serve as a template, or at least a starting point, for an enactivist conceptualization of readers' interactions with narratives. Enactive cognitive science began after all as a rebellion against representational positions, arriving at a kind of direct realism, whereas, in contrast, enactivist attempts to explain readers' engagement with fictional situations and characters come up against the uncircumventable problem of the sign-character of the narrative utterance, of its representing ${ }^{1}$ situations and events and actors (cf. most explicitly Caracciolo 2014: 9). Ingarden accounts how the reader transgresses the realm of semiotic representation towards embodied and culturally embedded cognition of objects in a presented world, but he also insists that representations (meanings of words and sentences) make up a basic stratum ${ }^{2}$ of the work and a vital aspect of the reader's experience. In other words, Ingarden's philosophy encompasses and reconciles both representational and anti-representational (enactivist in the narrower sense of the term) moments, while opening a vista on the cultural context of both reading literary texts and scholarly theories of this emotive-cognitive process.

1 At this point, I do not deem it necessary to differentiate between mental and semiotic representations. The reason for this will become clear later in the article, especially in section 2.

2 Alongside the strata of sounds, represented objects, and aspects, the two later of which are extra-semiotic or extra-linguistic. 
In this article, I will try to make evident that Ingarden's theory of the work, and of how it is or rather should be read, may help advance embodied and enactive aesthetics without falling for naïve empiricism, provided the theory in question is situated in its original context. I will demonstrate through the example of the relationship of East and Central European structuralism and Ingarden that unless the cultural environment of a theory of narrative is taken into consideration, one can hardly avoid misunderstandings regarding the basic notions of narrative cognition, such as perspective, attitude, memory, and aesthetical experience, which mean differently in different cultural ambiences. Ingarden's phenomenology of reading, when confronted with what have become "classic," structuralist positions, prompts us to rethink the very meaning of aesthetics in our scholarly culture and thus see more clearly the cultural presuppositions underlying present-day narrative studies drawing on second-generation cognitive science; presuppositions, which often pass unnoticed. The latent assumptions that contrast with Ingarden's attitude and become visible against the backdrop of his philosophy are, among others, the hasty close-the-gap syncretism and an identity fixation of "I can relate to that" type. The latent status of such assumptions might impede the development of enactive narrative science, if one agrees with the main thesis of the article that Ingarden succeeded in creating an enactive theory of narrative avant la lettre, even if it functioned only in a given cultural context. It is the fate of an embedded thought, though, that with time it loses its topicality. And it is up to us to decide whether it is possible and worth it to recover antiquated frames of minds for the sake of developing a philosophically sound enactivist approach to narrative.

Before I tackle in the last part of this article the general notion of aesthetics, as a broad concept in the framework of which partial issues acquire meaning, I will focus on one such issue. "Perspective" may serve as an excellent ground of comparison between structuralism and Ingarden's phenomenology, just as it is also a central notion of cognitive aesthetics and cognitive narrative studies (Jahn 1996, 1999; van Peer and Chatman eds. 2001; Grishakova 2002; Dancygier 2011: 87-116; Herman 2013: Ch. 4; Ciccoricco 2015: Ch. 1), being indispensable in embodied and enactive cognition. Cognitive narratology's focus on perspective, point of view, and focalisation is only a synecdoche of its overarching interest in the problems of the reception of narrative utterances (Sternberg 1978, 1990, 1992; Perry 1979; Gerrig 1993, 2011; Jahn 1997; Zerweck 2002; Eder 2003; Burke and Troscianko eds. 2017). Perspective is the necessary complement of enactivism's "embodied situatedness in a social world" as a definition of the human condition (Popova 2015: 4). Perspective is also central to the problems of empathy (Keen 2007, Keen 2013), immersion, simulation, and enaction: one needs after all a distance and an external point of view, so as to postulate the need for 
the liaison of empathy. Similarly, simulation and enactment is also always a simulation for someone who is situated in a chronotope: "simulation is essentially perspectival” (Dokic and Proust 2002: VIII). While structuralism, indeed, remained silent about or disapproving of immersion and enaction, and in this respect it differed essentially from second-generation cognitive science and cognitive narratology, Ingarden does treat the linguistic makeup of the work, the non-plus-ultra of the structuralist ontology of literature, as - to use a popular cognitivist term - merely an "affordance" (Gibson 1977, 1979; Herman 2000; Glenberg and Kaschak 2002; Glenberg et al. 2009) to construct, and imaginatively sightsee in, presented worlds. The notion of point of view also relates to the necessarily temporal reception of the work, which, in turn, emphasises the perspectival and enactive character of reception, taking place from a standpoint at least partially determined by and in the work, so that the reader is drawn into the "performance of literary communication" (Bartoszyński 1971: 127). As the prominent scholar of enactvism in narrative Yanna B. Popova put it: "The main avenue for coordination between reader and teller in a narrative is [...] temporal dynamics: flash-forwards and flashbacks in the sequence of events, the rapid tempo of a summary versus the slowness of a scene, and techniques like showing and telling are all temporal displacements, epistemological consequences of the proximal or distal self-positioning of a narrator. A literary story, much more than the stories we tell daily, relies on how the telling decides on and arranges what is told, which the reader enacts moment by moment in the process of sense-making” (Popova 2015: 77).

In the first step (section 2), I am referring to the philosophical tradition of direct realism, which was apparently invigorated by the theories of embodied cognition, to propose a way of conceiving first-person perspective on literary objects and events; a way which bypasses the representational, let alone computational, framework, and was taken by Ingarden. In section 3, I will tackle the issue of point of view in East and Central European structuralism by recalling its most general context of the dialectical relationship between synchrony and diachrony alongside its most general theory, that of Boris Uspenskii, who nearly equalled point of view with the essence of representation. Then, I move on to demonstrate, in what way the notion of perspective is central to Janusz Sławiński's structuralist reconstruction of the semantics of the narrative utterance, designed to prove that there is nothing in narrative which is not of semiotic (representational) nature. The interpretation of linguistic signs by the receiver is a space in which structuralism and phenomenology concur as they share a similar model of receptive temporality aiming to reduce the ambiguity of linguistic units and increase the predictability of meaning. They even, to a degree, they become enmeshed in each other. This degree is in Ingarden the threshold between the 
linguistic and the extralinguitic elements of the literary work. Generally speaking, temporal perspectivity of reception functions as the interface of divergent approaches to the literary work, structuralism and phenomenology, as well as a springboard to an entirely different concept of perception, memory, and time, "direct realism," to which Ingarden's distinct brand of phenomenology is related. I will, in section 4, describe this threshold between semiotics and the realm of direct realism, located in chapter 9 of Ingarden's Vom Erkennen des literarischen Werks (Ingarden 1968: 35-40, Ingarden 1973: 37-41) in the shape of the difference between passive and active reading. The latter kind of reading, which to my mind corresponds most closely to enaction, triggers the process of "objectification" (objektiwizacja, Objetivierung (Ingarden 1936b: 173-176, Ingarden 1968: 40-49, Ingarden 1973: 41-50), which, as I will demonstrate, transports the reader into the realm of direct realism with its peculiar temporal perspective and remarkable philosophical motivation. In the conclusion, I point to the major differences between present-day cognitivist aesthetics and Ingarden's approach, which was immersed in the culture of his time, and ask whether these differences hinder us from achieving as interesting results as Ingarden's.

\section{Enactive cognitive science, direct realism, and phenomenology}

In this section, I study the possibility of a first-person perspective on experienced objects, persons, and events, which would be not representational, but overtly pertain to direct realism. Even though direct realism motivates many a crucial facet in descriptions of the presented world and perspectives on that world, especially in theories of immersion, empathy, and enaction, it has never been presented as a coherent tradition in narratology. A theory is directly realistic by virtue of positing, quite plausibly, that the immersed subject has a perspective on a kind of objects and not signs of objects. One enacts people'a suffering, not graphemic marks. Put bluntly, a direct relation with objects is what distinguishes immersion from other possible attitudes towards the represented. Non-naïve direct realism in general is a fairly puzzling theory which assumes that while cognizing, remembering, or imagining, we encounter not mental "representations" of objects, but objects themselves, irrespective of whether one conceives of "representation" in terms of semiotics or representational or computational theories of the mind. Language expresses spontaneously the position of direct realism: I remember or recall a smell or a person, not their representations: "I beg leave to think with the vulgar, that when I remember the smell of the tuberose, 
that very sensation which I had yesterday, and which has now no more any existence, is the immediate object of my memory" (Reid 1997 [1764]: 168).

Per contra, first-generation cognitive science continued the long tradition of indirect or representative realism, i.e. the representational theory of perception and memory, which is best summed up in John Locke's famous remark that the mind "perceives nothing but its own ideas" (Locke 1975 [1690]: 4.4.3). Locke tellingly conceives the mind as a kind of apparatus which since the 1830s would become the emblem of representation - a camera ${ }^{3}$ : "the understanding is not much unlike a closet wholly shut from light, with only some little openings left, to let in external visible resemblances, or ideas of things without” (1975 [1690]: 2.9.17). In representative (indirect) realism, the subjective representation and its object are primary, primitive entities, while the relation between them is secondary and derived from intrinsic qualities of representing (subjective) and represented objects, e.g. likeness or convention. For non-naïve direct realists, beginning with Thomas Reid (1710-1796), a primordial, pre-conceived relation "Connexion" - links subjects to objects. ${ }^{4}$ The relation, ordinarily sustained by the bodily make-up of the subject, precedes logically and factually its cognizing and the cognized sides:

\begin{abstract}
The sceptic asks me, Why do you believe the existence of the external object which you perceive? This belief, sir, is none of my manufacture; it came from the mint of Nature; it bears her image and superscription; and, if it is not right, the fault is not mine: I even took it upon trust, and without suspicion. Reason, says the sceptic, is the only judge of truth, and you ought to throw off every opinion and every belief that is not grounded on reason. Why, sir, should I believe the faculty of reason more than that of perception?--they came both out of the same shop, and were made by the same artist; and if he puts one piece of false ware into my hands, what should hinder him from putting another? (Reid 1997 [1764]: 168-169).
\end{abstract}

As an heir of the belief that the mind manages only its own representations, set forth by both empiricist philosophy and introspective psychology, first-generation cognitive science assumed that mental states are mental representations (Fodor and Pylyshyn 1988), which have a double nature, being quasi-linguistic

3 Locke obviously had in mind a camera obscura ("dark room"), the prototype of photographic equipment.

4 "And in a like manner when certain sensations of my Mind are invariably accompanied with the conception and belief of certain external object, when it can be shewn that this connexion does not arise from Custom or Education, nor can be accounted for by any Law of the human mind hitherto known and received; We ought to hold this Connexion to be itself a Law of the human Mind, until we find some more general Law of which it is the consequence" (Reid 1997 [1764]: 260-261, cf. Copenhaver 70-71). 
and experiential at the same time. Mental representations correspond with linguistic signs on account of their semantic and syntactic nature as they convey meaning and are subject to combinatory (computational) procedures. As it seems, three properties of cognitivism's representation - properties which are traditionally, and not always fairly, attributed to structuralism as a theory of language, literature, culture, and cognition - provoked the rebellion of enactivism (Varela, Thompson, and Rosch 1991) against the representational theory of cognition and thus against indirect realism. The representationalists consider mental and for that matter semiotic representations abstract, arbitrarily related to their denotations, and amodal (a photograph of a chair and the lexeme "chair" refer to the same content).

In contradistinction to first-generation cognitivism and French structuralism, the structuralism of East European descent knew, obviously, a kind of language, which defied the vision of computational representation; this special kind, or function, of language came into sight in concrete utterances, was by no means amodal, but qualitative, and challenged the arbitrariness of the relations between singifiants and siginifiés. The "poetic language" or the "poetic function" of the East and Central European structuralists (Jakobson 1987 [1960]; Mukařovský 1940, Sławiński 1998 [1961]) was, nonetheless, limited to artistic utterances predominantly in verse and did not pertain to, or was marginalised in, studying narrative prose and communicative language. This vision of language could have been passed over with a good conscience by narratology up till the moment that "poetic language” became a model for linguistic behavior as such. Jakobson's notion of poetic language (Tabakowska 2015: 15), among other things, inspired Lakoff and Johnson (1980) to make a breach in the wall of linguistic and cognitive indirectness, which opened a perspective on embedding cognizing and "languaging" (Linell 2009: 247) in mutual interactions between the body and the environment. These interactions give, according to Lakoff and Johnson, rise to metaphors, in which we speak and think, even if, or especially when, we are telling stories in narrative prose. Metaphors definitively represent aspects of reality, but this sort of representation is directly realistic by virtue of being an immediate expression of humans' culturally situated embodiment. It has, by the way, already been stated that the rise of enactivism revived the tradition of direct realism: “'direct realism' has been usually reserved for the view that perceptual experience is constituted by the subject's standing in certain relations to external objects, where this relation is not mediated by or analyzable in terms of further, inner states of the agent. Thus, the brain in the vat could not have the same experiences as a normal veridical perceiver, because experience is itself already world-involving“ (Lyons 2017: 2.3.3.).

For Ingarden, the first encounter with a a work of literary art and the commencement of the cognition of that work, is obviously a reading of its printed 
text, which process he describes as a sensory, corporeal experience: ein imaginatives Hören, an imaginary hearing, of word sounds and melody accompanies the perception of typographical shapes. In some cases a silent Mitsprechen, saying together, occurs in the process, along with occasional "motor phenomena" (Ingarden 1973: 21, Ingarden 1968: 18). Ingarden stresses that this sensory stratum of sounds rooted in human physiology functions as a marker of fictionality (Ingarden 1968: 63-72, Ingarden 1973: 63-72), a trigger of aesthetic experience (Ingarden 1968: 231, Ingarden 1973: 222), and a generator of "aspects" that the reader projects onto the presented objects (Ingarden 1968: 56, Ingarden 1973: 56). At the end of the process of reading, the remembering of the strata of word sounds and organised phonetic formations contract them into a rhythm, which has clearly physiological roots (Ingarden 1936b: 186).

A narrative theory which takes enaction into account cannot forgo a kind of directly realistic presentation of objects, lest it ignores either the radical antirepresentational stance of second-generation cognitive science (Varela, Thompson and Rosch 1991; Noë 2004, 2010; O’Regan and Noë 2001; Thompson 2007; De Jaegher and di Paolo 2007; Hutto and Myin 2013) or the overtly (re-)presentational character of narrative utterances, which relate facts, events, etc. It seems intuitively obvious that if one intends to apply to narratives enactivism, hostile as it is toward classical computational cognitive science, one has to allow for a kind of representation (cf. Di Paolo, Rohde, and De Jaegher 2010). As Marco Caracciolo, the author of a seminal monograph of the enactivist approach to narrative, rightly put it: "anti-representationalism cannot be transferred 'as is' to conceptually and socio-culturally nuanced forms of experience” (Caracciolo 2014: 9). The representations conveyed by stories cannot, however, be regarded as indirectly realistic, otherwise we fall prey to conciliatory syncretism, which tolerates even own inconsistency.

Carracciolo's solution is a kind of dualism of representations and experiences in narrative, to which I would like to oppose Ingarden's triad of signs, intersubjective intentional objects and experiences, the last two being directly realistic. Because Carracciolo tacitly assumes that all representations are indirect, his dualism must be mutually exclusive: “characters' consciousness and experience cannot be represented as such by narrative texts; what we commonly call the 'representation of an experience' is the representation of the event in which a person (e.g., a fictional character) undergoes an experience" (Caracciolo 2014: 30). Experience is restricted to the reader, whose experiential gear literary representations trigger: "Representation works by referring to object-like entities (such as events, people, and things), while experience is a complex texture created by people's biological make-up and past experiences" (Caracciolo 2014: 30). However, it remains unclear how one could pertain to enactive, i.e. situated and 
embodied experience, and at the same time claim that an experience is not representable because it is not an event taking place in a certain time and space? "[E]xperience cannot be represented in the same sense as existents and events are represented, because it is neither object-like nor propositional" (Caracciolo 2014: 40). Quite the opposite, I say that experience is either a situated event (process, if you like) or it is neither embodied nor enactive. It seems as if Caracciolo assumed the position of a Cartesian dualism, albeit the attribute of the mind would now be not thinking, but experiencing. Yet extension remains the defining feature of a body as it is one of representation. The dualism of indirect representation and direct experience causes some other problems, as, firstly, it brings about the limiting of enaction or immersion to mere empathising with protagonists ${ }^{5}$ caused by bodiless experiences' necessity to couple with represented bodies, whereas Ingarden's triadic model allows for a more unconstrained relation of the reader to objects. (The reader is supposed to view objects from various perspectives.) Secondly, the character of memory traces, on which the reader falls back while experiencing the fate of a literary character, remains unclear. Should memories in this framework also be non-representative to be experiential? In real life they seem to be both sights, sounds, smells, objects and feelings. In short, enactive cognitive science of narrative necessitates a directly realistic concept of literary objects. My contention is that Ingarden's theory of cognising the literary work furnishes us with one such concept and that the concept gains clarity in confrontation with the structuralist approach to equivalent matters.

\section{From the point of view of structuralism}

Although perspective, point of view, and focalisation are metaphors connoting space ("internal," "external," "attitude towards," etc.), a scrutiny of the East and Central European theories of perspectival representation in narrative reveals that the superordinate character of "point of view" is temporal. This overarching importance of the time dimension is due to the fact that "perspective" pertains both to the modes of representation in the work and the reception of the work. The temporalisation of the space-related aspects of narrative utterances is embedded in a more general framework, which is, moreover, distinctive and representative of Husserl's phenomenology and East and Central European Structuralism since the late 1920s, when two sets of theses on linguistics and literature were formulated by Roman Jakobson and Iurii Tynianov (1971 [1928]), on the one hand, and, on the

5 Cf. Popova's discussion with Caracciolo's conception in Popova (2014 and 2015: 9, 84-85). 
other, by the members of the Prague Linguistic Circle ("Les thèses" 1982 [1929]), the leading member of which Jakobson was. Against Ferdinand de Saussure's and, more accurately, the Geneva School's sharp distinction between synchrony and diachrony, according to which only the former bears a systemic character, whereas linguistic changes are posited as "résultats fortuits de l'évolution phonétique" (de Saussure 1997 [1916]: 137). While de Saussure spoke about "le caractère aveugle des évolutions de sons” (de Saussure 1997 [1916]: 209), the East European structuralists posited a more dialectical relation between systemic diachrony and dynamic, internally temporalized, synchrony. In retrospect, Jakobson reaffirmed that the "two effective oppositions, synchrony/diachrony and static/dynamic, do not coincide in reality. Synchrony contains many a dynamic element, and it is necessary to take this into account when using a synchronic approach" (Jakobson and Pomorska 1985: 12). The dynamism of synchrony is relative to the receiver/perceiver of linguistic utterances, who may "feel" "obsolete elements of a linguistic system [...] as archaisms and new elements as the latest in fashion" (Jakobson and Pomorska 1985: 13). All in all, according to the East and Central European tradition of formalism and structuralism, epitomized by Roman Jakobson, spatial and temporal aspects of language (as well as other semantic systems) coincide, while being relative to the process of communication. This is the reason why such a spatial element as point of view turns out, when scrutinized by the East and Central European structuralists, to be ultimately temporal.

As is well-known, Boris Uspenskii (1973 [1970]) furnished the most comprehensive structuralist model of point of view, based on the understanding that this notion is fundamental in all representative arts, i.e. in the arts in which there is a difference between the infinite object represented (reality) and the finite representation thereof (painting, literature, film, theatre, etc.). The former has obviously to be re-construed and presented under a certain aspect. In this way the point of view of the receiver, to which this cropping of the world is addressed, became prototypical with respect to other occurrences of the phenomenon, such as different points of view inside the work. Uspenskii's model connects to the tradition of Slavic or East and Central European literary and art theory, foregrounding the broader context of communication, of which the work is a component; the Polish chapter of Slavic structuralism is even commonly called communicationism (cf. Dąbrowski 1987; Bartoszyński 2007). When Uspenskii relates his model specifically to literature, the distinction between internal and external points of view, regarded as elementary, is projected onto the elements implied with structural necessity by the notion of communication: the sender, the receiver, and the character (the object of communication). While the receiver essentially assumes an external perspective, the character takes on principally an internal point of view with relation to the representation as a whole. What 
distinguishes the sender (narrator, subject) is an ability to switch between internal and external viewpoints (Uspenskii 1973: 444-455). In this way, the spatial aspects of point of view appear as functions of the temporal processes of communication, which in the case of the narrative arts, prototypically literature, is reflected in the development in time of what is presented to the reader.

East and Central European structuralism and Ingarden's phenomenology share a receiver-oriented and, thus, temporal perspective on the literary work of art and its objectivities. But while structuralism, exemplified further on by Janusz Sławiński, tends to describe narrative temporality in terms of linguistic semantics, Ingarden's phenomenology both encompassed and transcended the linguistic strata of the work in the direction of represented entities (or objects) and views, with which the receiver deals directly. For Ingarden and his followers Henryk Markiewicz (1965: Ch. 5), Stanisław Eile (1973), and Jerzy Ziomek (1982), the language of a work is no more than a Husserlian "transitory object" (Ingarden 1968: 39 ("Durchgangsobjekt”); Ingarden 1973, 40 ("passageway")) on a way to, or a "tool" (Ingarden 1962: 6) for, constructing higher planes of a work. Moreover, Ingarden's description of the cognition of the literary work is internally divided in three with regard to the process of its reception in time. The reception operates on three interweaving planes: linguistic (semantic), objectual, and aesthetic, and thus contains three partially overlapping and interacting perspectives on the presented world.

As it will become clear soon in section 4, Ingarden's account of the comprehending of meanings of words and sentences corresponds, by virtue of its temporal shape, to the structuralist description of how the receiver is supposed to reconstruct the meaning of the narrative utterance. But whereas structuralism posits the continuity between meanings of sentences and the "grand semantic figures" of plot, narrator, scenery, etc., in Ingarden, the actualization of objects and aspects, albeit likewise temporally conditioned, goes beyond the realm of sign or representation towards direct - as Ingarden put it - "witnessing" of the occurrences in the presented world. The "objectification" of propositions, which are "synthetized" into intentional objects, resembles the structuralist projection of syntactic sings onto paradigmatic stocks; however it produces solid, intersubjective objects, which the reader may come back to and perceive under various perspectives. Moreover, objectification and concretization result in intentional objects' gaining quasi-independence from the synthetizing subject so that he or she may yield to their aesthetic qualities and, thus, engage in a third temporal layer of the experience of the aesthetic object rooted in the artistic work. Such an approach is beyond structuralism's scope of interest and tolerance.

Back to structuralism: The main goal of Sławiński's essay on the semantics of narrative utterance (1998 [1971]) is to get rid of any notions that pertain to the 
description of narrative, but do not correspond to, or simply come from, the dictionary of linguistic semantics. In this respect, Sławiński is drastically antiimmersive $^{6}$ as everything in the literary work is made of linguistic signs, even though some popular notions of narrative studies suggest otherwise and are, thus, symptoms of the "disease" of the language of narratology, as metaphysics is one in philosophy, according to Wittgenstein (cf. 2009 [1953]: § 133, 255). These notions imply that the level of the told (the narrative world) differs substantially from the level of telling, the latter obviously being made of words and not extralinguistic “objects" "designated" by propositions contained in literary works (Markiewicz 1965: 125). One of the condemned notions - alongside "events" and "persons" - is "point of view" (Sławiński 1998 [1971]: 101), as it suggests that there are some stable entities to be viewed from different perspectives.

Point of view, nevertheless, returns with a vengeance in Sławiński's account of how semantic units of a lower order add up to the grand figures of the presented world. Drawing on Viktor Vinogradov, Sergei Karcevskii, Valentin Voloshinov, Jan Mukařovský, and Lubomír Doležel, Sławiński (1998 [1971]: 115-117) sets out to demonstrate that laws analogous to those that rule the accumulation of the meaning of a sentence apply also to narrative. However, despite what the classical French narratologists might say, there is no such thing as a narrative syntax which would subjugate elements of narrative sequences by means of introducing hierarchical relations between them. In a tight spot like that, an East and Central European structuralist like Sławiński argues that works of literary art are products made of words that refer not to one system, that of language, but to at least two systems simultaneously: besides language they participate in the system of artistic tradition (that is, the structure of historically accumulated and culturally significant forms, cf. Sławiński 2001: 16). The latter system produces the narrative syntax.

Thus, the role of the all-encompassing syntax of narrative is taken over by a specifically narrative hierarchy - the hierarchy of points of view, precisely the difference between the narrator and the hero as determined by literary tradition (Sławiński 1998 [1971]: 117-121). The narrative levels differ usually through the language their representatives, the narrator and the protagonist, speak and through the perspective (internal/external) they assume. External and internal

6 ...more so than most East and Central European structuralists. For example, Boris Uspenskii set - in a way one would expect rather from a direct realist than a structuralist - the degree of reality against the sign character of a personage or an item. The marginal occurrences in a work highlight their sign character, in order to fulfill the role of a framework, which sets apart external and internal perspectives, while central characters and things have a greater degree of "probability": they are less sign-like and closer to the reality of life (Uspenskii 1973 [1970]: 163-165). 
perspectives resemble syntax by virtue of subjugating and distorting the dictionary meanings of language units. Similarly to the sound formation "address," which signifies different things in different syntactic contexts ("my address is...," "her address to the people...," "let me address this issue..."), the meaning of all words and sentences of a narrative is relative to the narrative instance in which they are uttered.

Just as in a grammatical sentence an interplay occurs between syntax and the meanings of particular words, in a narrative sequence there is a tension between perspectives (or levels) and meanings - between he or she who sees and describes and that which is spoken about. Points of view dovetail hierarchy, paradigm, non-linearity, the stability of literary tradition, and are confronted with informational flux, innovation, and entropy. The paradigmatic order opposes the syntagmatic influx of ever-new information. Grand semantic figures that emerge from this interplay of synthetic points of view and meanings accumulating and shifting over time - narrator, plot, hero, and virtual reader (Sławiński 1998 [1971]: 121) are, moreover, nothing less than different perspectives on the whole narrative utterance, language, and literary tradition, since they are determined by the set of relations they maintain with other elements both inside and outside the work. The narrator is, for example, determined by his or her position toward the presented world (events and environment), system of sociolects, the receiver, the author, literary tradition, traditional realisations of narration, and sanctioned narrative role models (Sławiński 1998 [1971]: 124). One should, moreover, add to the above that the whole semantics of narrative utterance is made relative to the perspective of the receiver, which is internally temporal. Enter phenomenology alonside internal time-consciousness.

\section{The triple temporal perspective of Ingarden's phenomenology}

Chapter 8 of Ingarden's The Cognition of the Literary Work of Art, devoted to the understanding of meanings of words and sentences, endorses the claim that phenomenology's temporal perspective on meaning conforms to structuralist tenets, especially to Karcevskii's $(1929,1931)$ model of sentence formation and reception, which was based on the semantics and the phonology of phrase. Karcevskii's model was adapted for the theory of literary utterances and poetic language by Mukařovský (1977 [1940]) and confirmed and reinforced subsequently by information theory. Sławiński (1998 [1971]) essentially translated Karcevskii and Mukařovský's model into the idiom of information theory as he assembled all these 
elements into his theory of narrative semantics. According to Sławiński, the predictability of the occurrence of an element increases with the accretion of a sequence. The boost of predictability is proportional to the diminishing of the polysemy and homonymy that pertain to linguistic units (disambiguation). ${ }^{7}$

Ingarden corroborates this model. While relying on Bergson's observation that the now is somehow extensive and on Husserl's description of ur-impressions, protentions, and retentions in internal time-consciousness, Ingarden demonstrates how words are deprived of their relations of homonymy and synonymy, in which they stand as parts of dictionary, once they become a part of a sequence that develops in time. One disambiguates words in view of the project of the whole sequence and a perspective on new sentences as well as the recollection of what has already been uttered (Ingarden 1968: 21-35, Ingarden 1973: 24-37). Vicinity in time or syntactic adjacency reduces the inherent ambiguity of words and sentences. The congruence with the structuralist description of chains of meaning extends even further, as Ingarden states that the compact meaningful whole, actualised in the operation of contextual disambiguation, cannot be reduced to the sum total of its elements, thus subscribing to the principle of holism, fundamental to structuralist thought (Ingarden 1968: 33, Ingarden 1973: 35: "In reading which is properly carried out, the content of work is organized quasiautomatically into an internally coherent, meaningful whole of a higher order and is not merely a random conglomeration of separate sentence meanings [...]").

The compliance between the phenomenologist and the structuralists is not surprising, far from it, since - as Danuta Ulicka pointed out (Ulicka forthcoming) Mukařovský's famous graphic illustration of the procedure of significative accumulation (Mukařovský 1940: 139, illustration 1) is isomorphic to Husserl's diagram of how retentions and protentions modify the significance of linear sequences (Husserl 1928: 447 [79], illustration 2).

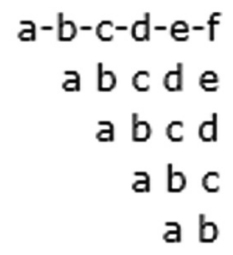

a

(Illustration 1)

7 Kukkonen 2014 proposes an analogous probabilistic approach to literary temporality in relation to the embodied reader and his or her learning skills. 


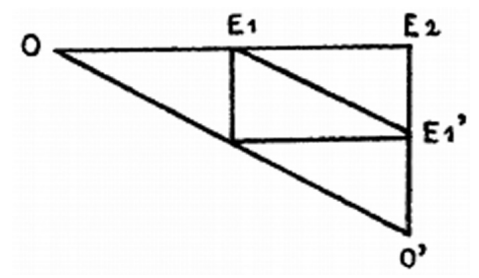

(Illustration 2)

Even though neither Karcevskii nor Mukařovský nor Sławiński quote Husserl, ${ }^{8}$ their structuralist model of the synthesis of smaller entities into the holistic meaning of a sequence, be it syntactic or narrative, tallies with Husserl's projectingharking-back attitude of the subject towards moments of time. And it also complies with Ingarden's as long as he remains on the plane of representational semantics. With respect to the representational stratum of meanings, phenomenology's point of view converges with structuralism's.

The threshold behind which lies the worldview of direct realism and the prospect of enaction is in Ingarden's The Cognition of the Literary Work of Art the difference between passive and active reading expanded on in chapter 9. Passive reading makes do with a structuralist-like comprehension of meanings; a passive reader does not make an effort - one essential for active reading - to relocate himor herself in the presented world with the intention of dealing directly with its objects (Ingarden 1968: 35-39, Ingarden 1973: 37-40). In active reading, however, the objects are "made" by the reader so that they can then stand "before our 'eyes"” (Ingarden 1973: 44, cf. Ingarden 1968: 43) as a "quasi-reality," which "has its own appearance, its own fates, and its own dynamics" (Ingarden 1973: 48, cf. Ingarden 1968: 47); although the reader actualises and upholds all the objects, he or she has to act as if he or she were a "witness to all [the] object and events" in the presented world (Ingarden 1973: 47, cf. Ingarden 1968: 46). Moreover, the reader has to assume "an aesthetic attitude" and give in to impressions that his or her alienated creations make on him or her, so as to enable an aesthetic experience (Ingarden 1968: 47, Ingarden 1973: 48). As paradoxical as it sounds, in the intricate and multifaceted process of the reception of the work of literary art, in which emotional, active, and passive moments intertwine (Ingarden 1968: 214-215, Ingarden 1973: 207), the reader actively construes objects, which he or she then

8 In his monography of Mukařovský, Sládek (2015: 194) explicitly denies Husserl's influence on the Czech scholar; cf. Ulicka (forthcoming) 
passively experiences as aesthetically valuable. The reader is active in order to be passive as the aesthetic experience is the ultimate goal of reading.

Thanks to his structuralist (Vodička 1982 [1941], Głowiński 1977) and reception-theory (Iser 1972) followers, Ingarden's theory of reception has been primarily associated with the concretisation of presented objectivities and aspects, which, by the way, were drawn by those followers into the realm of "representation" from that of direct realism. In this way, direct realism was supressed and, as a consequence, Ingarden's thought became distorted. However, in Ingarden, the more fundamental and time-oriented process of objectification must be conducted prior to any concretisation since only objects and their aspects can be concretised, and they emerge thanks to the objectifying action on the part of the active reader. Objectification, by means of which the reader transports him- or herself across the brink of direct realism, is the aspect of Ingarden's theory of reception, which modern-day theories of immersion and enaction should take cues from.

Ingarden's description of the process of objectification may at first confound the reader as it seems to be extremely multifarious, to the point of diffusion of mental activities. It may be carried out conceptually (gedanklich) or as a graphic, eidetic (anschaulich) procedure, or as a certain involuntary, spontaneous (unwillkürlich) and automatic sedimentation on objects of the knowledge conveyed by sentences (Ingarden 1968: 43-44, Ingarden 1973: 45). In other words, the reader objectifies the states of affairs (Sachverhalten) designated by sentences (Ingarden 1968: 42, Ingarden 1973: 43) by means of subscribing different predicates to one subject or by vividly imagining a personage or a prop, or by passively accruing the information contained in sentences. Still, all these (and probably more) heterogeneous synthetic activities, which Ingarden describes in detail, are just aspects of one synthetic operation on time leading to the emergence of spatiotemporal perspectives. All activities of objectification involve or presuppose a passage from the additive to the unifying (vereinheitlich) attitude towards information carried by the flow of reading (Ingarden 1968: 46, Ingarden 1973: 47). Each sentence in the chain designates a unique state of affairs (Ingarden 1968: 41, Ingarden 1973: 43), which the active reader organizes. While working, so to speak, against the stream of time, he or she binds unique states of affairs in bundles or imagines their aspects so that there emerge objectivities endowed with various qualities, some of which may ravish aesthetically, provided they have been additionally concretized. This operation encompasses, but also exceeds, the structuralist-like organizing meanings into entities of a higher order.

Thus, intentional aesthetical objects correspond with Husserl's noemata (Smith 1995: 340) as having two major components: first, an encompassing "sense" (in Ingarden it is rather a specific general quality), which integrates the 
various experiences with an object into a multifaceted experience of the various features of one and the same object. This is supplemented, secondly, by a "thetic" component, which determines the modality of our acts - whether we perceive or remember or imagine or think about an object. The conception of noemata may be modified in line with direct realism. As a complement of intentionality, Reid's "conception" is a way of being aware of an object as a certain kind of objects. Perceptions, imaginations, and memories are different species of conception, i.e. of directedness towards a different object, which is accompanied by different soto-speak intentional contents or beliefs as to the nature of the conceived. When one perceives an object, one is aware of its presence (not its representation) as a bearer of qualities and is convinced that the object exists. When remembering and even when imagining, one does not deal with a representation, an idea, but an object, about which one believes it is past resp. purely fantastical: "I conceive a centaur. This conception is an operation of the mind, of which I am conscious, and to which I can attend. The sole object of it is a centaur, an animal which, I believe, never existed" (Reid 1983 [1785]: 373). Ingarden's objectification both synthetises different pieces of information into one object and posits the product as an intersubjective intentional object, a part of a fictional world existing for the sake of its inherent aesthetical value. In this way, objectification makes it possible at all to speak about perspective or point of view in literature, since precisely this procedure, conducted on literary time, creates objects that, by virtue of being posited as objects and not signs, can be viewed from different angles by the literary protagonists (including the narrator) and, more importantly, by the reader. The reader may then concretise the objects and turn them into the aesthetic objects for him or her to contemplate in a specific state and time of aesthetic experiencing.

This alienation or emancipation of the presented world, with the objects of which the active reader deals directly, generates an endless number of aspects in which an aesthetic object can be perceived. Just as a sculpture cannot be seen from all angles at once, Ingarden says, there is no phase in the cognition of the literary work of art that would present an all-around image of the work and its world. This relative independence of the aesthetic object and its aspects results from Ingarden's anti-psychologism: the literary work cannot be reduced to cognitive acts of individual agents and brains - and this is why the aesthetic object has a reality outside its mental representations (Ingarden 1936b: 190). Parallaxes and distortions of perspective are possible in relation to the aesthetic object and the objects of the presented world in consequence of the reader's whimsical attention (Ingarden 1968: 91-94, Ingarden 1973: 90-93), which means - as Ingarden readily admits - that the objects exist somehow even in the moments when the reader is not reading about them. They do not exist potentially, in signs to be actualised, 
but as something actual or rather having been actualised. Different strata of the literary work are retained in different ways (Ingarden 1936b: 186-187), but once the objects are actively constituted, they acquire a kind of ontological independence from the mental acts of the reading. They exist rather in memory than in brain and the mind accesses them then from different perspectives. "It is as if we drifted away from an object, which still is and exists," Ingarden writes. "The reading of a work may be thus compared to visiting a land with the difference that this particular land is of our own making” (Ingarden 1936b: 185).

The aim of narrative according to Ingarden is experience. What else can induce the reader to become active and objectivize than an urge to experience something? What else promises a certain quality of an experience than culture that defines how to handle certain objects, such as a book or a magazine? Ingarden's reader has the liberty to remain passive and merely take note of the information conveyed in sentences. But the cultural forms of dealing with literary works promise the reader a special kind of experience, the aesthetic experience conditional on the effort of objectification and subsequent concretisation. In contradistinction to the structuralists, Ingarden does not describe the implied or perfect reader, who decodes and hierarchically arranges all information contained in a work acting as a counterpart to the work's intention, but a painstaking empirical reader, eager to acquaint him- or herself with the intersubjective objects as thoroughly as is possible from his or her unique perspective, because he or she belongs to a culture for which such objects and experiences are essential. They also give unparalleled pleasure.

\section{Conclusion: The significance of aesthetics}

Enactive cognitive science of narrative requires a sort of direct realism. Ingarden demonstrates that direct realism is anything but a naïve stance of gullibility, provided it is framed by the aesthetic attitude and, accordingly, aesthetic temporality. That aestheticism, which at all times presupposes that one brackets out one's everyday interests and passions, and enaction as a rule do not exclude, but mutually reinforce each other is best illustrated by the fact that the most aestheticist of philosophical positions, whose author claimed that only as an aesthetical phenomenon can existence and the world be justified (Nietzsche 1954: 40), was precisely Nietzsche's concept of the Dionysian. According to Nietzsche enaction was, along the Apollonian drive toward representation, the primitive phenomenon of human nature. The tragic chorus, Nietzsche claims, by no means facilitated an emphatic identification with the hero and in no way served as a template of emotional engagement for the viewer, but, on the contrary, it framed the action 
thus cutting it off from the outside world and enabling far more poignant and specific experience on the part of the viewer (Nietzsche 1954: 46).

This raises a vital question of whether an attempt on part of a representative of our contemporary scholarly culture to base a theory of enaction on Ingarden, or any other "old master" of phenomenology and East and Central European structuralism for that matter, is not bound to fail since the most prominent attempts at creating an enactive science of narrative stem from the mindset of "straddling the gaps" both between scholarly disciplines in "the true marriage of humanistic and scientific ways of understanding" (Popova 2015: 51) and between aesthetic and everyday experience. "The problem of how we understand narrative is not that different from how we understand people, actions, and events in the real world that narratives usually describe and represent" (Popova 2015: 5, cf. Popova 2015: 55). The drive toward immersion does not discharge anymore in the experience of an autonomous and singular aesthetic value as in Ingarden (1968: 86, 1973: 85), but instead in relating to other people's fortunes because they remind us of our background (Caracciolo 2014: 124). Or maybe it is, conversely, impossible to create enactive narrative science without revivifying the notions of autonomous aesthetics and the specificity of the aesthetic experience?

According to Ingarden, the reader's striving for immersion aims at an aesthetic and not "vicarious," an exceptional not a second-hand, experience. To put it bluntly, the painstaking reader of Madame Bovary, having made an effort and objectified the presented world, does not want to learn how it is to cheat on a husband, but what the unique aesthetic value of this novel is. In his study of the cognition of the work of literary art, Ingarden does not name a single reason why the reader is supposed make an effort and read actively and responsibly, taking up the toil of objectification and concretisation. In the culture that Ingarden was engulfed in, aesthetic value was autotelic and absolute. One associated oneself with persons and props in literary works for the sake of the unconditional aesthetic value, the experience of which was the real aim and "idea" of the existence of the

9 "The view that stories provide kinds of vicarious experiences for readers is not new and has long been entertained by philosophers and critics alike. In notions such as Walton's (1990) 'make believe', Ryan's (2001) immersion and 'virtual reality', and Fludernik's (1996) 'experientiality' there is a level of consensus among scholars that as readers we simulate the lives and problems of fictional characters in an essentially 'off-line' way, that is, in a way that separates the real and imaginary worlds” (Popova 2015: 6; cf. Caracciolo 2014: 3-5). At times, readers' experiences surpass in intensity their daily interactions: "we can enact the experience of another person in real life too-that is to say, empathize with him or her-but we do not do it as often (and as intensely) as in reading texts" (Caracciolo 2014: 113). 
literary work (Ingarden 1968: 86, Ingarden 1973: 85). The culture ascribed to aesthetics a separate, self-contained, and self-sufficient dwelling within its boundaries. Just as the language of the literary work is, according to Ingarden, subjugated to the objectification of quasi-independent entities, so are "artistic values," inherent to the work of literary art, only relative to the absolute aesthetical value, emerging in the process of active reading (Ingarden 1968: 305, Ingarden 1973: 294). When Ingarden met with Roman Jakobson at a conference in Warsaw in 1960, the latter delivered his signature talk "Linguistics and Poetics" (1987 [1960]), ${ }^{10}$ to which Ingarden responded with a talk "Poetik und Sprachwissenschaft" ("Poetics and Linguistics," 1962). In it, Ingarden argued that poetics deals first and foremost with self-sufficient aesthetic values pertaining to the objectivities the reader helps construct and then admires, and not with linguistic transitory objects. With his appeal not to miss the objects for their signs, he appears as the last of the Mohicans and at the same time a precursor of enactivism.

Harking back to a different cultural and philosophical setting, Ingarden's model averts the danger of naïve empiricism, which mistakes analogy for causation (Turner and Pöeppel 1983; Schrott and Jacobs 2011; Jacobs et al. 2015) or makes the specific aesthetic object disappear in favour of looking for the neuronal substratum of aesthetic experience, which eventually turns out not to be specific to aesthetics (Zeki and Nash 1999; Cinzia and Vittorio 2009; Mar 2011, Chatterjee 2011; Jacobs 2011 and Jacobs 2015; Nadal 2013; Chatterjee and Vartanian, 2014, Starr 2013: 24-25; Bohrn et al. 2013; Zeki 2014). In Ingarden, for example, empathy is not a deliberate naivety of taking propositions for people (cf. Keen 2007 and Keen 2013; Agosta 2010; Hogan 2015), sited in mirror-neurons (Keen 2006), characterised at times as the be all end all of morality (Nussbaum 1996), but an instrument of objectification, which supports the reconstruction of the relations between the elements of the presented world (Ingarden 1968: 244-248, Ingarden 1973: 235-239), and in this way facilitates the objectifying metamorphosis of the material substratum of a work (marble, words, paints, etc.) into presented objects and aspects (Ingarden 1968: 210-211, Ingarden 1973: 203-204). This is empathy for the sake of the absolute aesthetic value. Ingarden enables the theorizing of what I would call the immersion of witnessing, which grants the reader autonomy and freedom to move freely across the presented world, lest he or she is shackled to the position of the narrator or the hero.

10 The Polish of its authorised translation by Jakobson's soon-to-be wife, Krystyna Pomorska, is even more telling with view of the direction of the dependency: "Poetyka w świetle językoznawstwa" ("Poetics in the Light of Linguistics," 1960). 
By the same token, Ingarden's notion of immersion differs from a mere illusion or delusion, not by the degree of disbelief, but in a qualitative way, because it is subordinated to autonomous aesthetic value. Time is vital not only in view of synthetizing the meaning of sentences and turning the states of affairs they designate into objectivities that one can contemplate under different aspects. The process of reading encompasses yet another layer of time, i.e. the temporality of the aesthetic experience, which intermingles with other time perspectives so that a polyphony of different intervals arises. The aesthetic experience has a starting point, Ursprungsqualität, an originary quality (Ingarden 1968: 194-209, Ingarden 1973: 188-202 as “originally attractive quality”), which catapults one out of ordinary life with its casual sequentiality and corresponding temporal flow into a truly Bergsonian and Proustian realm of la durée and direct realism. Direct realism applies to an expanse designated by aesthetics as exterritorial in relation to practical life with the aim of enabling the acknowledgement of absolute aesthetic value in a truly "thetic" fashion: yes, I want this unique value to exist (Ingarden 1968: 225, Ingarden 1973: 217). Direct realism with regard to autonomous aesthetical qualities is the condition of this acknowledgment since the subject has to commune directly with this value, or else it is not absolute, but mediated. Further, direct acknowledgement of this value is the whole point of making and receiving works of art, at least this was the tacit presupposition in the culture that Ingarden was active in. Only ex-post does the reader/receiver connect the time of the aesthetic experience with the practical, linear time of and for practicalities (Ingarden 1968: 200-201, Ingarden 1973: 191-194).

All things considered, the post-structuralist student of narratives is invited by Ingarden to rethink contemporary notions of aesthetics and the aesthetic experience in order to draw from the treasury of Ingarden's theory, which from our perspective appears uncannily futuristic and antiquated at the same time.

Acknowledgement: This article is an output of the Project "A Century of Theory. One Hundred Years of Theoretical Research in Poland" supported by the Polish National Research Center (NCN2014/13/B/HS2/00310)

\section{References}

Agosta, Lou. 2010. Empathy in the context of philosophy. London: Palgrave Macmillan. Alber, Jan \& Monika Fludernik (eds.). 2010. Postclassical narratology: approaches and analyses. Columbus: Ohio State University Press.

Bartoszyński, Kazimierz. 1971. Zagadnienie komunikacji literackiej w utworach narracyjnych. In Janusz Sławiński (ed.), Problemy socjologii literatury, 127-148. Wrocław: Ossolineum. 
Bartoszyński, Kazimierz. 2007. 0 “zwrotach”, czyli kilka uwag o tak zwanej komunikacji literackiej. Teksty drugie 3. 233-237.

Caracciolo, Marco. 2014. The experientiality of narrative. An enctaivist approach. Berlin \& New York: De Gruyter.

Caracciolo, Marco, Cécile Guédon, Karin Kukkonen, Sabine Müller. 2017. The promise of an embodied narratology: integrating cognition, representation and interpretation. In Per Krogh Hansen, John Pier, Philippe Roussin, Wolf Schmid (eds.), Emerging vectors of narratology, 435-460. Berlin \& New York: De Gruyter.

Burke, Michael \& Emily T. Troscianko (eds.). 2017. Cognitive literary science: dialogues between literature and cognition. Oxford: Oxford University Press.

Chatterjee, Anjan. 2011. Neuroaesthetics: a coming of age story. Journal of cognitive neuroscience 23(1). 53-62.

Chatterjee, Anjan \& Oshin Vartanian. 2014. Neuroaesthetics. Trends in cognitive sciences 18(7). 370-375.

Ciccoricco, David. 2015. Refiguring minds in narrative media. Lincoln: University of Nebraska Press.

Cinzia, Di Dio \& Gallese Vittorio. 2009. Neuroaesthetics: a Review. Current opinion in neurobiology 19(6). 682-687.

Copenhaver, Rebecca. 2004. A Realism for Reid: Mediated but Direct. British journal for the history of philosophy 12(1). 61-74.

Dąbrowski, Stanisław. 1987. W sprawie teoretycznej dezautonomizacji literatury: w kręgu wypowiedzi komunikacjonistów. Pamiętnik literacki 78(2), 155-183.

Dancygier, Barbara. 2011. The language of stories: a cognitive approach. Cambridge: Cambridge University Press.

Dokic, Jérôme \& Joëlle Proust. 2002. Introduction. In Jérôme Dokic \& Joëlle Proust (eds.), Simulation and knowledge of action (Advances in Consciousness Research 45). Amsterdam \& Philadelphia: John Benjamins Publishing.

Eder, Jens. 2003. Narratology and cognitive reception theories. In Tom Kindt \& Hans-Harald Müller (eds.), What is narratology? Questions and answers regarding the status of a theory. 277-301. Berlin: de Gruyter.

Eile, Stanisław. 1973. Światopogląd powieści. Wrocław: Ossolineum.

Fludernik, Monika \& Greta Olson. 2011. Introduction. In Greta Olson (ed.), Current trends in narratology, 1-36. Berlin \& New York: De Gruyter.

Fodor, Jerry A. 1975. The language of thought. Cambridge, Mass.: Harvard University Press.

Fodor, Jerry A. 1987. Psychosemantics: the problem of meaning in the philosophy of mind. Cambridge, Mass.: MIT Press.

Fodor, Jerry A. and Pylyshyn, Zenon W. 1988. Connectionism and cognitive architecture: A critical analysis. Cognition 28. 3-71.

Gerrig, Richard J. 1993. Experiencing narrative worlds: on the psychological activities of reading. New Haven: Yale University Press.

Gerrig, Richard J. 2011. Conscious and unconscious processes in readers' narrative experiences. In Greta Olson (ed.), Current trends in narratology, 37-60. Berlin \& New York: de Gruyter.

Gibson, James J. 1977. The theory of affordances. In Robert Shaw and John Bransford (eds.), Perceiving, acting and knowing: towards an ecological psychology, 127-143. Hillsdale: Erlbaum.

Gibson, James J. 1979. The ecological approach to visual perception. Boston: Houghton Mifflin. 
Glenberg, Arthur M., Raymond Becker, Sussan Klötzer, Lidia Kolanko, Silvana Müller \& Mike Rinck. 2009. Episodic affordances contribute to language comprehension. Language and cognition. 1 (1). 113-135.

Glenberg, Arthur M., Michael P. Kaschak. 2002. Grounding language in action. Psychonomic bulletin and review. 9. 558-565.

Głowiński, Michał. 1977. 0 konretyzacji. In Michał Głowiński, Style odbioru: szkice o komunikacji literackiej, 93-115. Kraków: Wydawnictwo Literackie.

Grishakova, Marina. 2002. The Acts of Presence Negotiated: Towards the Semiotics of the Observer. Sign systems studies 30(2). 529-553.

Herman, David. 1997. Scripts, Sequences, and Stories: Elements of a Postclassical Narratology, pmla 112(5). 1046-1059.

Herman, David. 1999. Introduction: Narratologies. In David Herman (ed.), Narratologies: new perspectives on narrative analysis, 1-30. Columbus: Ohio State University Press.

Herman, David. 2000. Narratology as a Cognitive Science. Image \& narrative 1, http://www. imageandnarrative.be/inarchive/narratology/davidherman.htm (accessed 13 March 2018).

Herman, David. 2013. Storytelling and the sciences of mind. Cambridge, Mass.: MIT Press. Hogan, Patrick Colm. 2015. What literature teaches us about emotion: synthetizing affective science and literary studies. In Lisa Zunshine (ed.), The Oxford handbook of cognitive literary studies, 273-290. Oxford: Oxford University Press.

Husserl, Edmund. 1928. Vorlesungen zur phänomenologie des inneren zeitbewusstseins, ed. by Martin Heidegger. Halle a. S.: Niemeyer.

Hutto, Daniel D. and Eric Myin 2013. Radicalizing enactivism: basic minds without content. Cambridge, MA: MIT Press.

Ingarden, Roman. 1936b. Formy poznawania dzieła literackiego. Pamiętnik literacki 33(1/4). 163-192.

Ingarden, Roman.1962. Poetik und Sprachwissenschaft. Poetics - poetyka - poetika. 3-9. Warszawa: PWN; and The Hague: Mouton.

Ingarden, Roman. 1968. Vom Erkennen des literarischen Kunstwerks. Tübingen: Niemeyer.

Ingarden, Roman. 1973. The cognition of the literary work of art, translated by Ruth Ann Crowley \& Kenneth R. Olson. Evanston: Northwestern University Press.

Iser, Wolfgang. 1972. The reading process: a phenomenological approach. New literary history 3(2). 279-299.

Jacobs, Arthur M. 2011. Neurokognitive Poetik: Elemente eines Modells des literarischen Lesens. In Raoul Schrott, Arthur M. Jacobs, Gehirn und Gedicht: wie wir unsere Wirklichkeiten konstituieren, 492-520. München: Hanser.

Jacobs, Arthur M. 2015. Neurocognitive Poetics: Methods and Models for Investigating the Neuronal and Cognitive-Affective Bases of Literature Reception. Frontiers in human neuroscience 9. https://doi.org/10.3389/fnhum.2015.00186 (accessed 13 March 2018).

Jacobs, Arthur M., Melissa L.-H. Võ, Benny B. Briesemeister, Markus Conrad, Markus J. Hofmann, Lars Kuchinke, Jana Lüdtke, Mario Braun. 2015. 10 years of BAWLing into affective and aesthetic processes in reading: what are the echoes? Frontiers in psychology 6. https:// doi.org/10.3389/fpsyg.2015.00714 (accessed 13 March 2018)

De Jaegher, Hanne and di Paolo, Ezequiel. 2007. Participatory sense-making: An enactive approach to social cognition. Phenomenology and cognitive sciences, 6. 485-507.

Jahn, Manfred. 1996. Windows of focalization: deconstructing and reconstructing a narratological concept. Style 30, 241-267. 
Jahn, Manfred. 1997. Frames, preferences, and the reading of third-person narratives: toward a cognitive narratology. Poetics today 18(4), 441-468.

Jahn, Manfred. 1999. More aspects of focalization: refinements and applications. In John Pier (ed.), Recent trends in narratological research (GRAAT 21), 85-110. Tours: Presses universitaires François-Rabelais.

Jakobson, Roman. 1987 [1935]. The dominant. In Roman Jakobson, Language in literature, ed. by Krystyna Pomroska \& Stephen Rudy, 85-110. Cambridge, Mass.: Harvard University Press.

Jakobson, Roman. 1987 [1960]. Linguistics and poetics. In Roman Jakobson, Language in literature, ed. by Krystyna Pomroska and Stephen Rudy, 62-94. Cambridge, Mass.: Harvard University Press.

Jakobson, Roman. 1960. Poetyka w świetle językoznawstwa, translated by Krystyna Pomorska. Pamiętnik literacki 51(2). 431-473.

Jakobson, Roman \& Pomorska, Krystyna 1985. Dialogue on time in language and literature, In Roman Jakobson. Verbal art, verbal sign, verbal time, ed. by Krystyna Pomorska, 11-24. Minneapolis: University of Minnesota Press.

Jakobson, Roman \& Tynianov, lurii. 1971 [1928]. Problems in the study of language and literature. In Ladislav Matejka \& Krystyna Pomorska (eds.), Readings in russian poetics: formalist and structuralist views, 79-81. Cambridge, Mass.: MIT Press.

Karcevskii, Sergei. 1929. Du dualisme asymétrique du signe linguistique. Travaux du cercle linguistique de Prague 1. 88-92.

Karcevskii, Sergei. 1931. Sur la phonologie de la phrase. Travaux du cercle linguistique de prague 4. 188-227.

Keen, Suzanne. 2006. A Theory of Narrative Empathy. Narrative 14(3). 207-236.

Keen, Suzanne. 2007. Empathy and the novel. Oxford: Oxford University Press.

Keen, Suzanne. 2013. Narrative empathy. In Peter Hühn, John Pier, Wolf Schmid \& Jörg Schönert (eds.): Living handbook of narratology. Hamburg: Hamburg University. http://www.lhn.unihamburg.de/article/narrative-empathy (accessed 13 March 2018).

Kukkonen, Karin. 2014. Presence and prediction: the embodied reader's cascades of cognition. Style, 48.3. 367-384.

Lakoff, George and Johnson, Mark. 1980. Metaphors we live by. Chicago: University of Chicago Press.

Linell, Per. 2009. Rethinking language, mind, and world dialogically: interactional and contextual theories of human sense-making. Charlotte, NC: Information Age Publishing.

Locke, John. 1975 [1690]. An essay concerning human understanding. Oxford: Clarendon Press.

Lyons, Jack. 2017. Epistemological problems of perception. In. The Stanford encyclopedia of philosophy (Spring 2017 Edition), Edward N. Zalta (ed.), URL = https://plato.stanford.edu/ archives/spr2017/entries/perception-episprob/ [12.08.2018].

Mar, Raymond A. 2011. The neural bases of social cognition and story comprehension. Annual review psychology 62. 103-134. https://doi.org/10.1146/annurev-psych-120709-145406 (accessed 13 March 2018).

Markiewicz, Henryk. 1965. Gtówne problemy wiedzy o literaturze. Kraków: Wydawnictwo Literackie.

Mukařovský, Jan. 1940. O jazyce básnickém. Slovo a slovesnost 6(3). 113-145. http://sas.ujc. cas.cz/archiv.php?art=343 (accessed 13 March 2018).

Mukařovský, Jan. 1970 [1936]. Aesthetic function, norm and value, translated by Mark E. Suino. Ann Arbor: University of Michigan Press. 
Mukařovský, Jan. 1977 [1940]. On Poetic Language. In Jan Mukařovský, The word and verbal art: selected essays, trans. and ed. John Burbank and Peter Steiner, 1-64. New Haven and London: Yale University Press.

Noë, Alva. 2004. Action in perception, Cambridge, MA: MIT Press

Noë, Alva. 2010. Vision without representation. In. Gangopadhyay, Nivedita. Madary, Michael, Spicer, Finn (eds.). Perception, action, and consciousness: sensorimotor dynamics and two visual systems, New York: Oxford University Press.

Nadal, Marcos. 2013. The experience of art: insights from neuroimaging. Progress in brain research 204. 135-158.

Nietzsche, Friedrich. 1954. Werke in drei Bänden, Bd. 1. München: Carl Hanser.

Peer, Willie van \& Chatman, Seymour (eds.). 2001. New perspectives on narrative perspective. Albany: SUNY Press.

Perry, Menakhem. 1979. Literary Dynamics: How the Order of a Text Creates Its Meanings. Poetics today $1(1)$ and 2. 35-64, 311-361.

Pier, John. 2011. Is There a French Postclassical Narratology? In Greta Olson (ed.), Current trends in narratology, 336-367. Berlin \& New York: De Gruyter

Popova, Yanna B. 2014. Review of Caracciolo, Marco. The experientiality of narrative. An enactivist approach. Enthymema XI, https://riviste.unimi.it/index.php/enthymema/article/view/ 4590/4681 [10.8.2018]

Popova, Yanna B. 2015. Stories, meaning, and experience. Narrativity and enaction. New York and London: Routledge.

Prince, Gerald. 2008. Classical and/or Postclassical Narratology. Esprit créateur 48(2). 115-123.

O'Regan, Kevin and Noë, Alva. 2001. A sensorimotor account of vision and visual consciousness. Behavioral and brain sciences, 25 (4). 883-975.

Reid, John. 1997 [1764]. An inquiry into the human mind on the principles of common sense, ed. by Derek R. Brookes. University Park: Pennsylvania State University Press.

Reid, Thomas. 1983 [1785]. Essays on the intellectuals power of man. Philosophical works, vol. 1. Hildesheim, Zürich, New York: Georg Olms.

Saussure, Ferdinand de. 1997 [1916]. Cours de linguistique generale. Paris: Payot \& Rivages.

Schrott, Raoul \& Arthur M. Jacobs. 2011. Gehirn und Gedicht: wie wir unsere Wirklichkeiten konstruieren. München: Hanser.

Sládek, Ondřej. 2015. Jan Mukařovský. Život a dílo. Brno: Vyžádané přednášky.

Sławiński, Janusz. 1998 [1961]. Wokót teorii języka poetyckiego. In Janusz Sławiński, Dzieło język - tradycja. Prace wybrane, ed. Bolecki, Włodzimierz, t. 2. 74-96. Kraków: Universitas.

Sławiński, Janusz. 1998 [1971]. Semantyka wypowiedzi narracyjnej. In Janusz Sławiński, Dzieło język - tradycja. Prace wybrane, ed. Włodzimierz Bolecki, t. 2. 97-125. Kraków: Universitas.

Sławiński, Janusz. 2001. Co nam zostało ze strukturalizmu. Teksty drugie 5. 15-19.

Smith, David Woodruff. 1995. Mind and body. In Barry Smith (ed.), The Cambridge companion to Husserl, 323-393. Cambridge: Cambridge University Press.

Smith, Richard Cándida (ed.). 2011. Art and the performance of memory. London and New York: Routledge

Sommer, Roy. 2012. The merger of classical and postclassical narratologies and the consolidated future of narrative theory 1. Diegesis 1. https://www.diegesis.uni-wuppertal.de/index.php/ diegesis/article/view/96/93\#sdendnote1sym (accessed 13 March 2013)

Starr, G. Gabrielle. 2013. Feeling beauty. The neuroscience of aesthetic experience. Cambridge: MIT Press. 
Sternberg, Meir. 1978. Expositional modes and temporal ordering in fiction. Baltimore: Johns Hopkins University Press.

Sternberg, Meir. 1990. Telling in time (i): chronology and narrative theory. Poetics today 11(4). 901-948.

Sternberg, Meir. 1992. Telling in time (ii): chronology, teleology, narrativity. Poetics today 13(3). 463-541.

Tabakowska, Elżbieta. 2015. Translation studies meets linguistics: pre-structuralism, structuralism, post-structuralism. Acta universitatis carolinae. Philologica 3 / translatologica pragensia, IX. 1-23.

Les theses 1982 [1929]. Theses presented to the first congress of Slavic philologists in Prague, 1929. In Peter Steiner (ed.), The prague school: selected writings, 1929-1946, 3-31. Austin: University of Texas Press.

Thompson, Evan. 2007. Mind in life: biology, phenomenology, and the sciences of mind, Cambridge, MA: Harvard University Press.

Turner, Frederick \& Ernst Pöeppel. 1983. The neural lyre: Poetic meter, the brain and time. Poetry 142(5). 277-309.

Ulicka, Danuta. Forthcoming. Czas i pamięć. Ruch literacki.

Uspenskii, Boris. 1973 [1970]. A poetics of composition: the structure of the artistic text and typology of a compositional form. Irvine: University of California Press.

Uspenskii, Boris. 1973. Strukturnaia obshnost' raznykh vidov iskusstva: obshchie principy organizacii proizvedeniia v zhyvopisi i literature. In Josette Rey-Debove (ed.), Recherches sur les systemes signifiants: symposium de Varsovie 1968, 443-480. The Hague: Mouton.

Varela, Francesco J., Thompson, Evan, Rosch, Eleanor. 1991. The embodied mind: cognitive science and human experience. Cambridge, MA: MIT Press.

Vodička, Felix. 1982 [1941]. The Concretization of the Literary Work: Problems of the Reception of Neruda's Works. In Peter Steiner (ed.), The prague school. Selected writings, 1929-1946, 103-134. Austin: University of Texas Press.

Wittgenstein, Ludwig. 2009 [1953]. Philosophical investigations. Wiley-Blackwell.

Zeki, Semir. 2014. Neurobiology and the Humanities. Neuron 84(1). 12-14. http://dx.doi.org/ 10.1016/j.neuron.2014.09.016 (accessed 13 March 2018).

Zeki, Semir \& Nash John. 1999. Inner vision: an exploration of art and the brain. Oxford: Oxford University Press.

Zerweck, Bruno. 2002. Der cognitive turn in der Erzähltheorie: kognitive und ,natürliche’ Narratologie. In Ansgar Nünning \& Vera Nünning (eds.), Neue Ansätze in der Erzähltheorie. Trier: Wissenschaftlicher Verlag Trier.

Ziomek, Jerzy. 1982. Fikcyjne pole odniesienia a problem quasi-sądów. In Michał Głowiński \& Janusz Sławiński (eds.), Wypowiedź literacka a wypowiedź filozoficzna. Wrocław: Ossolineum. 